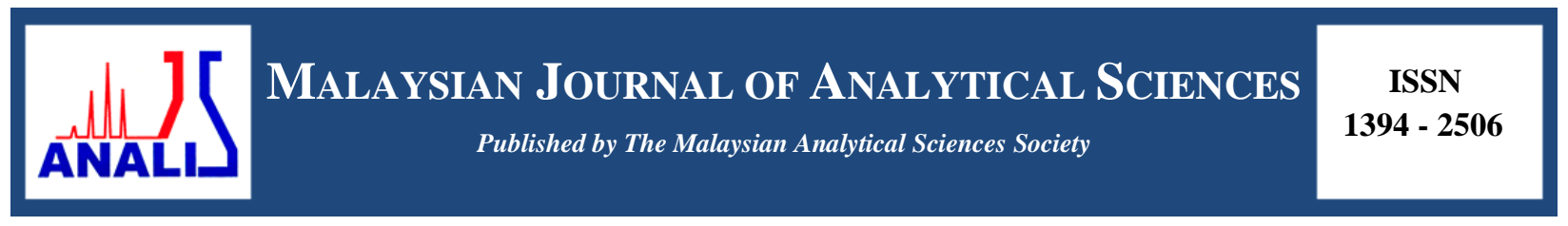

\title{
ENHANCEMENT AND OPTIMIZATION OF SINENSETIN EXTRACT FROM Orthosiphon stamineus USING SUPERCRTITICAL CARBON DIOXIDE EXTRACTION
}

\author{
(Peningkatan dan Pengoptimuman Ekstrak Sinensetin dari Orthosiphon stamineus Menggunakan \\ Kaedah Pengekstrakan Bendalir Supergenting Karbon Dioksida) \\ Ahmad Hazim Abdul Aziz ${ }^{1}$, Mohd Azizi Che Yunus²*, Lee Nian Yian ${ }^{1}$, Zuhaili Idham ${ }^{1}$, Fahim Rithwan $^{3}$, \\ Hafizah Mohd Hadzri ${ }^{4}$, Ana Najwa Mustapha ${ }^{5}$ \\ ${ }^{l}$ Centre of Lipids Engineering and Applied Research (CLEAR), Ibnu Sina Institute for Scientific and Industrial Research \\ ${ }^{2}$ Faculty of Chemical and Energy Engineering \\ Universiti Teknologi Malaysia, 81310 UTM Johor Bahru, Johor, Malaysia \\ ${ }^{3}$ NF Marketing, 41050 Meru, Selangor, Malaysia \\ ${ }^{4}$ Mukjizat International Sdn Bhd., 40100 Shah Alam, Selangor, Malaysia \\ ${ }^{5}$ Faculty of Chemical Engineering, \\ Universiti Teknologi MARA,40450 Shah Alam, Selangor, Malaysia \\ *Corresponding author: azizi@cheme.utm.my
}

Received: 16 April 2017; Accepted: 7 March 2018

\begin{abstract}
Sinensetin is a rare valuable flavonoid compound that contains 5 methoxy groups attached on the flavone backbone. This compound is abundantly established in citrus peel and can also be found in medicinal herb, 'misai kucing'. Scientifically, 'misai kucing' is known as Orthosiphon stamineus; mostly used to treat kidney stones by old folks. Orthosiphon stamineus was listed in National Key Economic Area (NKEA) as contributor towards the Malaysian Economic Growth. Thus, this study was conducted with objectives to determine suitable modifier for supercritical carbon dioxide $\left(\mathrm{SC}-\mathrm{CO}_{2}\right)$ extraction and to optimize the $\mathrm{SC}-\mathrm{CO} 2$ extraction condition (pressure, temperature and average particle size) on the concentration of sinensetin. Water, methanol and acetone were used on the determination of modifier for $\mathrm{SC}-\mathrm{CO}_{2}$ extraction by using water bath extraction at $40{ }^{\circ} \mathrm{C}$ in 8 hours. The results showed that acetone gave the highest percentage of sinensetin extract of $0.11 \%$. Therefore, acetone was used as a modifier to enhance the extraction of sinensetin. The concentration of sinensetin was increased and the highest percentage of sinensetin obtained was $6.99 \%$. Response surface methodology (RSM) through Box-Behnken design via Design Expert Software was applied to optimize the $\mathrm{SC}-\mathrm{CO}_{2}$ conditions. The first-order polynomial was used to express the percentage of sinensetin with $\mathrm{R}^{2}$ value of 0.542 . The optimum SC- $\mathrm{CO}_{2}$ operating condition was $30 \mathrm{MPa}, 40{ }^{\circ} \mathrm{C}$ and $308.24 \mu \mathrm{m}$ with sinensetin percentage of $4.35 \%$. Hence, $\mathrm{SC}-\mathrm{CO}_{2}$ with small amount of modifier was the best method to extract sinensetin as compared to water bath extraction method.
\end{abstract}

Keywords: sinensetin, supercritical carbon dioxide, orthosiphon stamineus, misai kucing, optimization

\section{Abstrak}

Sinensetin merupakan sebatian flavonoid yang jarang ditemui dan sangat berharga terdiri daripada 5 kumpulan metoksi yang terikat pada struktur flavone. Sebatian ini banyak dijumpai dalam kulit limau dan juga boleh didapati dalam herba 'misai kucing'. Secara saintifik, 'misai kucing' dikenali sebagai Orthosiphon stamineus; di mana 'misai kucing' digunakan untuk merawat batu karang oleh orang-orang tua. Orthosiphon stamineus telah disenaraikan dalam Kawasan Ekonomi Utama Negara (NKEA) sebagai penyumbang kepada pertumbuhan ekonomi negara. Oleh itu, kajian ini dijalankan dengan objektif untuk menentukan pelarut tambahan yang sesuai untuk pengekstrakan bendalir supergenting karbon dioksida $\left(\mathrm{SC}^{\left.-\mathrm{CO}_{2}\right)}\right.$ dan mengoptimumkan 
pemboleh ubah $\mathrm{SC}-\mathrm{CO}_{2}$ (tekanan, suhu dan purata saiz zarah) terhadap kepekatan sinensetin. Air, metanol dan aseton telah digunakan untuk menentukan pelarut tambahan untuk pengekstrakan $\mathrm{SC}-\mathrm{CO}_{2}$ dengan menggunakan pengekstrakan rendaman air pada suhu $40{ }^{\circ} \mathrm{C}$ dalam masa 8 jam. Keputusan menunjukkan bahawa aseton memberikan peratusan sinensetin tertinggi sebanyak $0.11 \%$. Oleh itu, aseton digunakan sebagai pelarut tambahan untuk meningkatkan pengekstrakan sinensetin dalam SC$\mathrm{CO}_{2}$. Kepekatan sinensetin meningkat dan peratusan tertinggi sinensetin diperoleh ialah 6.99\%. Kaedah gerak balas permukaan (RSM) melalui rekabentuk Box-Behnken menggunakan perisian Design Expert untuk mengoptimumkan pemboleh ubah SC$\mathrm{CO}_{2}$. Polinomial tertib pertama digunakan untuk menyatakan peratusan sinensetin dengan nilai regrasi $\mathrm{R}^{2}$ ialah 0.542 . Keadaan optimum bagi $\mathrm{SC}-\mathrm{CO}_{2}$ adalah $30 \mathrm{MPa}, 40^{\circ} \mathrm{C}$ dan $308.24 \mu \mathrm{m}$ dengan peratusan sinensetin sebanyak $4.35 \%$. Oleh itu, $\mathrm{SC}-\mathrm{CO}_{2}$ dengan sedikit pelarut tambahan adalah kaedah terbaik untuk mengekstrak sinensetin berbanding kaedah pengekstrakan rendaman air.

Kata kunci: sinensetin, bendalir supergenting karbon dioksida, orthosiphon stamineus, misai kucing, pengoptimuman

\section{Introduction}

By 2020, Malaysian government targeted Malaysia to become a developed and high-income country comparable with Japan, Korea and other developed countries. Economic Transformation Programme (ETP) was introduced by Malaysian government on 2010 as an approach to increase growth gross national income (GNI) per capita of USD 15,000 and create million new jobs. In the program, agriculture sector is one of the main sector listed in the National Key Economic Areas (NKEAs) with other 11 sectors. The 16 Entry Point Projects (EPPs) have been pointed out to urge growth in this sector and one of them is high-value herbal products. The first phase of this EPP focused on five main local herbs which are tongkat ali, misai kucing, hempedu bumi, dukung anak and kacip fatimah while ensuring the supply for research and development (R\&D) is sufficient.

Orthosiphon stamineus, generally known as misai kucing, is a traditional herb that is mostly used as tea beverage and herb medicine in Malaysia and Indonesia. People consume the herb to treat kidney stones, urinary tract infections, diabetes and high blood pressure. Recent studies revealed that approximately 116 chemical compounds were isolated from $\mathrm{O}$. stamineus, providing medicinal benefit to human health [1]. In addition, researchers also found scientific evidences on health benefits of O. stamineus extract such as diuretic and hypouricemic effect [2], anti-infective activity [3], anti-hyperglycemic activity [4] and anti-diabetic activity [5]. These evidences are associated with the presence of main secondary metabolites in $\mathrm{O}$. stamineus extract such as rosmarinic acid, eupatorin, 5-hydroxy-3', 4',6,7-tetramethoxyflavone (TMF) and sinensetin [6].

Sinensetin is the most potent compound in $O$. stamineus because it is a rare polymethoxylated flavone which abundantly found in citrus peel [7]. Sinensetin has antiagiogenesis activity. Angiogenesis is the formation of a mature blood vessel network through expansion and remodeling of the pre-existing vascular primordium. It plays a crucial role in the development of cancer [8,9]. In addition, sinensetin has chemo-sensitizing effect that can reverse P-glycoprotein as mediated multidrug resistance (MDR) by increasing the intracellular accumulation of drugs [10].

Extraction of plant materials like $O$. stamineus could be done by various procedures. Conventional method of extraction like Soxhlet and water bath extraction method commonly used massive amount of organic solvent associates with long extraction regime and high temperature. These approaches however, risk the degradation of interest bioactive compounds. This disadvantage gives rise to non-conventional method such as supercritical fluid extraction (SFE) which is more environmentally friendly, shorter extraction regime and give better quality of extract. Carbon dioxide is believed to be an ideal solvent for SFE because of its critical temperature $\left(31.1^{\circ} \mathrm{C}\right)$ which is relatively ambient, and moderate critical pressure of 7.38 MPa. However, low polarity of carbon dioxide limits the solubility exhibited by polar compound. This has becomes the main problem in SFE because most of the bioactive compounds in plant materials are polar. Nevertheless, this can be overcome by introducing a small amount of organic solvent (e.g., ethanol, methanol, and acetone) that can act as modifier in the system to increase the range of solvating strength to extract more polar compounds and significantly enhance the polarity of carbon dioxide [11]. In this study, supercritical carbon dioxide $\left(\mathrm{SC}-\mathrm{CO}_{2}\right)$ extraction was introduced to attain a better yield extract of $\mathrm{O}$. stamineus leaves compared with other extraction methods. Moreover, few studies have proved that $\mathrm{SC}-\mathrm{CO}_{2}$ extraction gave better yield of extraction on plant matrices such as manjakani [12], dukung anak [13], jering [14] and rubber seed [15] compared to conventional extraction method. 
Response surface methodology (RSM) is widely used to optimize the operating parameters of $\mathrm{SC}-\mathrm{CO}_{2}$ extraction based on experimentally-fitted empirical model that described the response of the affecting parameters. The response can be represented graphically either in 3-D space or as contour plot that help visualize the shape of the response. There are different softwares that can be used to perform RSM such as Statistica, Design Expert, Minitab, and SPSS. Design Expert software widely used because it is more user friendly than others [16-19].

In this study, selection of the most effective solvent as modifier in $\mathrm{SC}_{-} \mathrm{CO}_{2}$ to enhance the quality of the sinensetin in the extract was conducted using water bath extraction method. Meanwhile, optimization of $\mathrm{SC}-\mathrm{CO}_{2}$ extraction parameters (pressure, temperature and average particle size) was conducted using RSM to obtain high percentage of sinensetin from $O$. stamineus leaves.

\section{Sample preparation}

\section{Materials and Methods}

Dried leaves of $O$. stamineus were purchased from Herbagus Trading, Penang. The leaves were ground in several sizes of 300, 500 and $700 \mu \mathrm{m}$. The ground leaves were sealed in a plastic seal bag and kept in a freezer at $-20{ }^{\circ} \mathrm{C}$ to keep the freshness of the leaves.

\section{Water bath extraction}

Polarity of sinensetin was not known. Hence, various concentrations of solvents were used in this study to investigate. A total of 10 grams $O$. stamineus ground leaf was extracted using water, methanol (100\% and 50\%) and acetone $(100 \%$ and $70 \%)$ for 8 hours at $40{ }^{\circ} \mathrm{C}$ in water bath [20].

\section{Supercritical fluid extraction}

A schematic diagram of the fabricated $\mathrm{SC}-\mathrm{CO}_{2}$ rig used in this study is shown in Figure 1. The fabricated $\mathrm{SC}-\mathrm{CO}_{2}$ unit was consisted of a $50 \mathrm{~mL}$ extraction vessel, high-pressure pump (Supercritical 24, Lab Alliance), modifier pump (Series II Pump, Lab Alliance), automated back pressure regulator (Jasco, BP-2080 Plus) and oven (U10, Mermert) as extraction chamber. Total flowrate of $4 \mathrm{~mL} / \mathrm{min}$ with $5 \%$ modifier was used, where $3.8 \mathrm{~mL} / \mathrm{min}$ of 99.99\% pure carbon dioxide (Kras, Instrument and Services, Johor, Malaysia) were pumped in the system with 0.2 $\mathrm{mL} / \mathrm{min}$ of $99.5 \%$ analytical grade acetone (Merck Millipore) [21]. A total of $5 \mathrm{~g}$ samples were required for 90 minutes extraction regime under these conditions: temperature $\left(40-80{ }^{\circ} \mathrm{C}\right)$ and pressure $(10-30 \mathrm{MPa})$ for various average particle sizes $(300,500$ and $>500 \mu \mathrm{m})$.

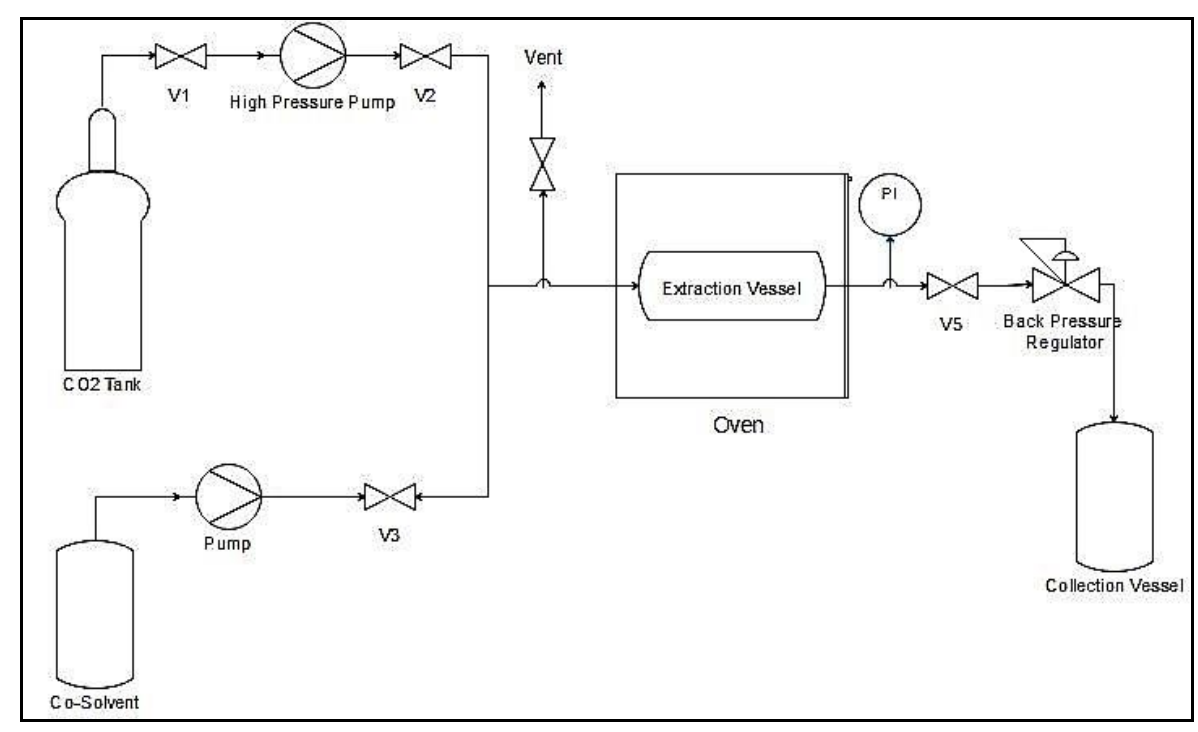

Figure 1. Schematic diagram of $\mathrm{SC}-\mathrm{CO}_{2}$ extraction unit 
Enhancement of the sinensetin recovery from $O$. stamineus was performed using $\mathrm{SC}-\mathrm{CO}_{2}$. However, $\mathrm{SC}-\mathrm{CO}_{2}$ has disadvantage on the polar compound extract because carbon dioxide is a nonpolar compound. Hence, addition of modifier in small amount into the process could enhance the amount of sinensetin recovery. Acetone was selected as a modifier in this study based on the highest percentage of sinensetin $(0.11 \%)$ in the extract during water bath extraction compared to the other solvents as shown in Figure 2.

\section{High performance liquid chromatography}

The extract of $O$. stamineus was filtered using a $0.45 \mu \mathrm{m}$ filter paper prior to use. HPLC analysis was performed using an Agilent Technologies series 1100 system/series equipped with an automatic injector, a column oven, and a diode array UV detector. A LiChrosorb RP-18 $(250 \mathrm{~mm} \times 4.6$ i.d. $\mathrm{mm}, 5 \mu \mathrm{m}$ particle size) (Merck Darmstadt, Germany) was used. The temperature was maintained at $25^{\circ} \mathrm{C}$, with injection volume of $20 \mu \mathrm{L}$ and flow rate of 1 $\mathrm{mL} / \mathrm{min}$. Sinensetin was separated using methanol: water: tetrahydrofuran (45:50:5 v/v) as mobile phase for 30 minutes [20]. The peaks were detected at $340 \mathrm{~nm}$ and identified by standard substance. Sinensetin standard was purchased from ChromaDex. The amount of sinensetin found in the extract $(\mu \mathrm{g} / \mathrm{g})$ was calculated by using equation 1 as follows and expressed in percentage of sample used:

$$
\mathrm{Q}(\mu \mathrm{g} / \mathrm{g})=(\mathrm{A}-\mathrm{C}) / \mathrm{S} *(\mathrm{~V} / \mathrm{W})
$$

where as $\mathrm{Q}$ is defined as amount of sinensetin in the sample, $\mathrm{A}$ is peak area of chromatogram, $\mathrm{V}$ is dilution volume $(\mathrm{mL}), \mathrm{S}$ is slope of calibration curve, C is intercept of the calibration curve and $\mathrm{W}$ is weight of the sample $(\mathrm{g})$.

\section{Optimization}

Design Expert software version 6 was used in this study to determine the optimum condition of $\mathrm{SC}-\mathrm{CO}_{2}$ process. The ranges of pressure, temperature and average particle size were $10-30 \mathrm{MPa}, 40-80{ }^{\circ} \mathrm{C}$ and $300-500 \mu \mathrm{m}$ respectively. 15 runs were conducted in optimization process with responses of sinensetin percentage in the extract of $O$. stamineus as shown in Table 1. The experimental data were fitted with response surface model generated by the Design Expert software using Box-Behnken design. Box-Behnken is better compared to central composite design because it avoids experiments at extreme conditions and more economical [22]. The analysis of variance (ANOVA) was also used to evaluate the quality of the fitted model through calculation of the correlation factor, $\mathrm{R}^{2}$ and F-test. The $\mathrm{F}$ value calculated should be higher than $\mathrm{F}$ value tabulated (from $\mathrm{F}$ table), indicating that the response surface model is significant.

Table 1. Experimental design

\begin{tabular}{lcccc}
\hline Run & Pressure & Temperature & $\begin{array}{c}\text { Average } \\
\text { Particle Size }\end{array}$ & Sinensetin \\
\hline 1 & 10 & 40 & 500 & 3.20 \\
2 & 30 & 40 & 500 & 6.99 \\
3 & 10 & 80 & 500 & 1.03 \\
4 & 30 & 80 & 500 & 1.68 \\
5 & 10 & 60 & 300 & 1.51 \\
6 & 30 & 60 & 300 & 2.67 \\
7 & 10 & 60 & 700 & 1.74 \\
8 & 30 & 60 & 700 & 2.24 \\
9 & 20 & 40 & 300 & 2.24 \\
10 & 20 & 80 & 300 & 1.76 \\
\hline
\end{tabular}


Table 1 (cont'd). Experimental design

\begin{tabular}{ccccc}
\hline Run & Pressure & Temperature & $\begin{array}{c}\text { Average } \\
\text { Particle Size }\end{array}$ & Sinensetin \\
\hline 11 & 20 & 40 & 700 & 2.52 \\
12 & 20 & 80 & 700 & 1.61 \\
13 & 20 & 60 & 500 & 2.65 \\
14 & 20 & 60 & 500 & 2.35 \\
15 & 20 & 60 & 500 & 2.91 \\
\hline
\end{tabular}

\section{Enhancement of the sinensetin extract}

\section{Results and Discussion}

By analyzing the area of the chromatograms and compare it with calibration curve graph, it was possible to estimate the percentage of sinensetin in the extract. Water bath extraction method with various solvent showed that different solvent gave different percentage of sinensetin extract. Figure 2 shows that $100 \%$ acetone give the highest percentage of sinensetin $(0.11 \%)$, followed by $70 \%$ acetone $(0.10 \%), 100 \%$ methanol $(0.08 \%)$, 50\% methanol $(0.03 \%)$, and water $(0.03 \%)$. Similar result was reported by Akowuah et al., where acetone gave the highest percentage of sinensetin $(0.32 \%)$ compared to methanol $(0.15 \%)$, chloroform $(0.18 \%)$ and ethyl acetate $(0.21 \%)$ from $1 \mathrm{~g}$ of dry powder methanol extract [20].

This phenomenon can be explained according to "like dissolve like" principle, where solvents would extract and attract compounds of similar polarity. In this case, sinensetin was the target compound and was mostly obtained in acetone. Hence, it can be concluded that sinensetin is a polar compound based on the result shows in Figure 2.

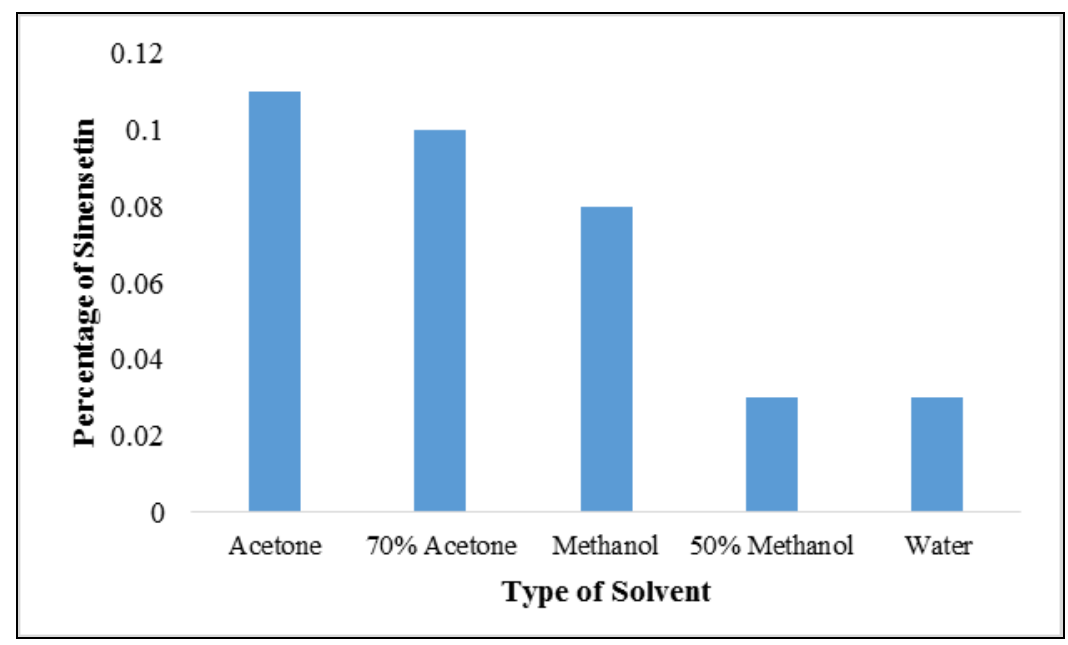

Figure 2. Effect of various solvents on the percentage yield of sinensetin

Therefore, acetone was selected to be used as modifier in the $\mathrm{SC}-\mathrm{CO}_{2}$ extraction, where, binary-solvent system gave high quality of extract compared with mono-solvent system [23]. Table 1 indicates that $\mathrm{SC}_{-} \mathrm{CO}_{2}$ extraction enhanced the percentage of sinensetin in the $O$. stamineus extract. The highest percentage of sinensetin extract was $6.99 \%$ at $30 \mathrm{MPa}, 40^{\circ} \mathrm{C}$ and $500 \mu \mathrm{m}$. This is because high pressure of $30 \mathrm{MPa}$ and low temperature of $40{ }^{\circ} \mathrm{C}$ increase the solvent density; hence improved the solubility of sinensetin and enhanced the percentage of sinensetin extract. 


\section{Optimization of the sinensetin extract}

Evaluation of the response surface model and analysis of variance (ANOVA) were performed using data in Table 1 by using Design Expert software version 6.0. Based on the ANOVA test presented in Table 2, it is possible to evaluate the influence of extraction conditions analyzed regarding the response percentage of sinensetin.

Table 2. Descriptive of ANOVA test

\begin{tabular}{llllll}
\hline Source & Df & $\begin{array}{l}\text { Sum of } \\
\text { Square }\end{array}$ & $\begin{array}{l}\text { Mean } \\
\text { Square }\end{array}$ & $\begin{array}{l}\text { F } \\
\text { calculated }\end{array}$ & $\begin{array}{l}\text { T } \\
\text { Table }\end{array}$ \\
\hline Regression & 3 & 14.49 & 4.83 & 4.35 & 3.59 \\
Residual & 11 & 12.26 & 1.11 & & \\
Total & 14 & 26.75 & & & \\
\hline
\end{tabular}

According to the ANOVA data, only temperature is statistically significant $(\mathrm{p}<0.05)$ considering a significance level of $95 \%(\alpha=0.05)$. The average particle size did not show a significant influence in the percentage of sinensetin in the extract according to descriptive index ( $\mathrm{p}$ value) of $98.17 \%$. Therefore, in the present conditions, assumption that there is a relationship between the average particle size and the percentage of sinensetin should be rejected. Other parameters should be considered to replace the average particle size such as solvent flowrate, extraction time and concentration of modifier.

The analysis also elucidates that the regression is statistically significant, so it can be applied to the model to describe the variation of sinensetin percentage in the extract. With $\mathrm{p}$ value of 0.0302 for linear regression, linear model should be adopted. The F calculated value that is larger than F tabulated value indicates that the model is accepted. Thus, the regression coefficients of response surface were estimated for the linear model resulting in equation 2 without interaction of the parameters.

$$
\% \text { Sinensetin }=4.296+0.076 \mathrm{X}_{1}-0.055 \mathrm{X}_{2}-4.375 \mathrm{E}-05 \mathrm{X}_{3}
$$

From the analysis, coefficient of determination, $\mathrm{R}^{2}$ was equal to 0.542 and the adjusted coefficient of determination, $\mathrm{R}^{2}$ adjusted was equal to 0.417 . The coefficient of determination value was quite low but still acceptable. The validity of the model was further confirmed by non-significant value of $(\mathrm{p}>0.05)$ for lack of fit, which indicates a linear model without interaction as statistically significant for the response.

By using equation 2, response surface graph was generated as shown in Figure 3. From Figure 3(a), as pressure increase the density of the solvent increased, and decreased the distance between molecules; hence strengthening the interaction between the solvent into the system and enhance the amount of sinensetin. In contrast, as temperature increase, the amount of sinensetin extract decrease. This effect can be attributed to the decomposition of heatsensitive component (sinensetin) during extraction at higher temperature. As can be seen in Figure 3(b) and (c), particle size of the sample did not affect the extraction of the sinensetin. Therefore, the optimum $\mathrm{SC}-\mathrm{CO}_{2}$ extraction conditions to extract sinensetin based on the equation 2 are $30 \mathrm{MPa}, 40{ }^{\circ} \mathrm{C}$ and $308.24 \mu \mathrm{m}$ with the sinensetin percentage as $4.35 \%$. 

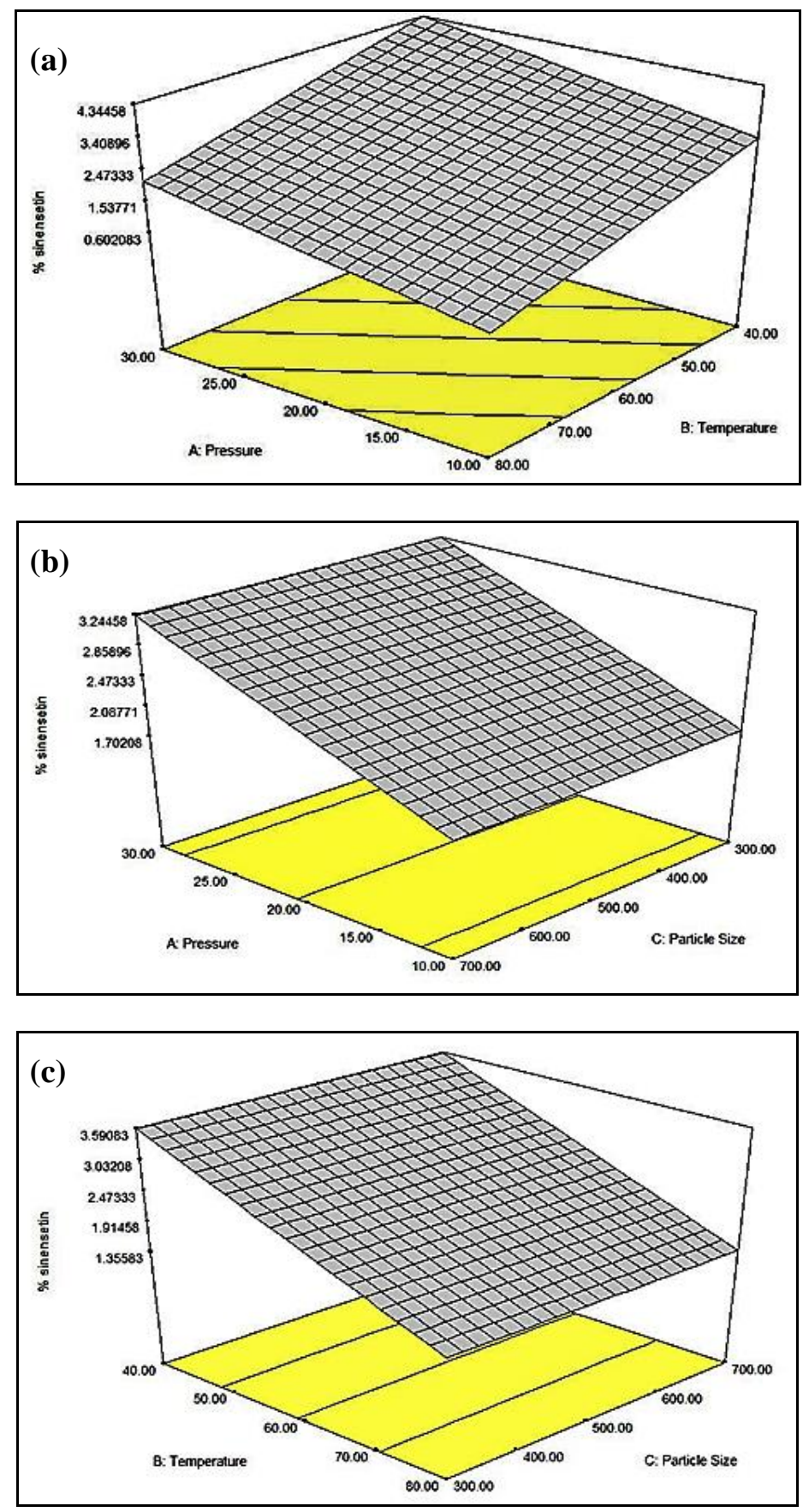

Figure 3. Response surface plot for two independent variables effect on percentage of snensetin: (a) pressure and temperature; (b) pressure and average particle size; (c) temperature and average particle size

\section{Determination of sinensetin}

The sinensetin standard was diluted into different concentrations to develop a calibration curve and gave an equation of $\mathrm{Y}=63.99 \mathrm{X}-794.02$ with $\mathrm{R}^{2}$ value is 0.9711 . The peak of sinensetin from the extract was validated by comparing the retention time with standard. Figure 4(a) indicates a chromatogram of sinensetin standard at $20 \mathrm{ppm}$ 
and Figure 4(b) indicates the chromatogram of the O. stamineus extract. Both the standard and sinensetin from the extract resolved and eluted at 3.9 minutes.
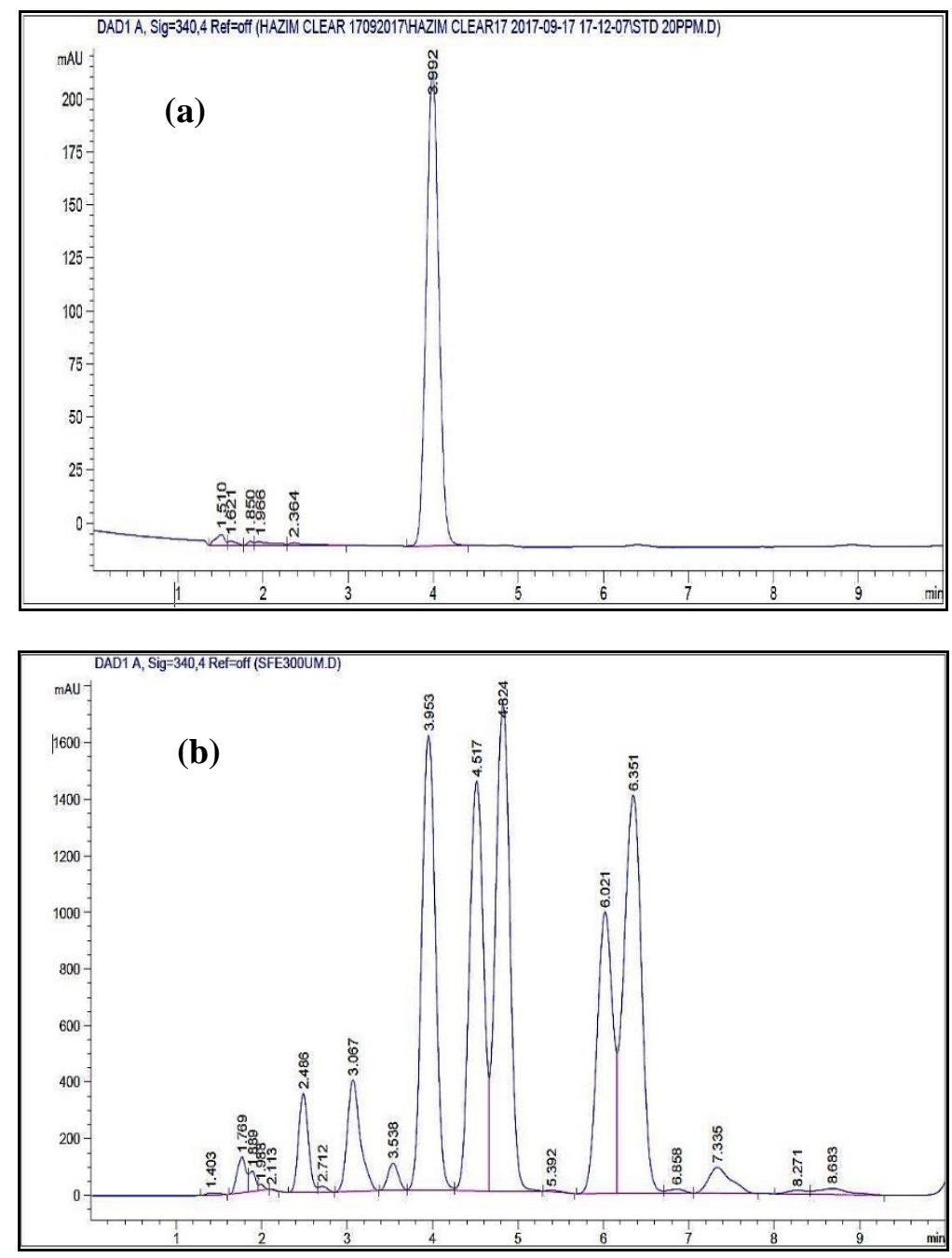

Figure 4. Chromatogram of sinensetin: (a) standard at $20 \mathrm{ppm}$ and (b) extract of $O$. stamineus using $\mathrm{SC}^{-\mathrm{CO}_{2}}$ extraction

\section{Conclusion}

$\mathrm{SC}-\mathrm{CO}_{2}$ is the best extraction technique that can be used to extract sinensetin from $O$. stamineus leaves compared with conventional technique. This is due to the high selectivity properties of $\mathrm{SC}-\mathrm{CO}_{2}$ method. It was proved that SC- $\mathrm{CO}_{2}$ could enhance the amount of sinensetin extract from $0.11 \%$ to $6.99 \%$ in short extraction regime using small amount of organic solvent. At pressure of $30 \mathrm{MPa}$ at $40{ }^{\circ} \mathrm{C}$, and $308.24 \mu \mathrm{m}$ particle size, the highest sinensetin amount $(4.35 \%)$ was obtained by using response surface methodology. Even though the coefficient of determination $\left(\mathrm{R}^{2}\right)$ value was low (0.542), the model is still acceptable and significant, and the average particle size of the sample can be neglected. In addition, retention time of sinensetin in chromatogram was observed at 3.9 minutes.

\section{Acknowledgement}

This research is fully supported by Universiti Teknologi Malaysia and Johor State Government Fund (R.J130000.7709.4J260). The authors fully acknowledged Johor State Government and Universiti Teknologi Malaysia for the approved fund which makes this important research viable and effective. 


\section{References}

1. Adnyana, I. K., Setiawan, F. and Insanu, M. (2013). From ethnopharmacology to clinical study of Orthosiphon stamineus Benth. International Journal of Pharmacy and Pharmaceutical Sciences, 5: 66-73.

2. Arafat, O. M., Tham, S. Y., Sadikun, A., Zhari, I., Haughton, P. J. and Asmawi, M. Z. (2008). Studies on diuretic and hypouricemic effects of Orthosiphon stamineus methanol extracts in rats. Journal of Ethnopharmacology, 118(3): 354-360.

3. Kong, C., Tan, M. W. and Nathan, S. (2014). Orthosiphon stamineus protects Caenorhabditis elegans against Staphylococcus aureus infection through immunomodulation. Biology Open, 3(7): 644-655.

4. Mohamed, E. A. H., Mohamed, A. J., Asmawi, M. Z., Sadikun, A., Ebrika, O. S. and Yam, M. F. (2011). Antihyperglycemic effect of Orthosiphon stamineus benth leaves extract and its bioassay-guided fractions. Molecules, 16(5): 3787-3801.

5. Mohamed, E. A., Ahmad, M., Ang, L. F., Asmawi, M. Z. and Yam, M. F. (2015). Evaluation of $\alpha$-glucosidase inhibitory effect of $50 \%$ ethanolic standardized extract of Orthosiphon stamineus benth in normal and streptozotocin-induced diabetic rats. Evidence-Based Complementary and Alternative Medicine, 2015: 1-6.

6. Singh, M. K., Gidwani, B., Gupta, A., Dhongade, H., Kaur, C. D., Kashyap, P. P. and Tripathi, D. K. (2015). A review of the medicinal plants of genus orthosiphon (Lamiaceae). International Journal of Biological Chemistry, 9(6): 318-331.

7. Gaydou, E. M., Bianchini, J. P. and Randriamiharisoa, R. P. (1987). Orange and mandarin peel oils differentiation using polymethoxylated flavone composition. Journal of Agricultural and Food Chemistry, 35(4): 525-529.

8. Lam, I. K., Alex, D., Wang, Y. H., Liu, P., Liu, A. L., Du, G. H. and Yuen Lee, S. M. (2012). In vitro and in vivo structure and activity relationship analysis of polymethoxylated flavonoids: Identifying sinensetin as a novel antiangiogenesis agent. Molecular Nutrition and Food Research, 56(6): 945-956.

9. Sahib, H. B., Aisha, A. F., Yam, M. F., Asmawi, M. Z., Ismail, Z., Salhimi, S. M., Othman, N. H. and Majid A. M. S. A. (2009). Anti-angiogenic and antioxidant properties of Orthosiphon stamineus benth. methanolic leaves extract. International Journal of Pharmacology, 5(2): 162-167.

10. Choi, C. H., Sun, K. H., An, C. S., Yoo, J. C., Hahm, K. S., Lee, I. H., Sohng, J. K. and Kim, Y. C. (2002). Reversal of p-glycoprotein-mediated multidrug resistance by 5,6,7,3',4'-pentamethoxyflavone (Sinensetin). Biochemical and Biophysical Research Communications, 295(4): 832-840.

11. Edward, R., Qiubai, S. U. N., Zhiqiang, Z., Chongmin, Z. and Wei, G. O. U. (2009). Mini-review: Green sustainable processes using supercritical fluid carbon dioxide. Journal of Environmental Sciences, 21(6): 720 726.

12. Nasir, N. H. M., Salleh, L. M., Nur Syukriah, A. R., Ya'akob, H., Yunus, M. A. C. and Majid, F. A. A. (2015). Total phenolic content and antioxidant activity of Quercus infectoria galls using supercritical $\mathrm{CO}_{2}$ extraction technique and its comparison with Soxhlet extraction. Pertanika Journal of Science and Technology, 23(2): 287-295.

13. Hadzri, H. M., Yunus, M. A. C., Zhari, S. and Rithwan, F. (2014). The effects of solvents and extraction methods on the antioxidant activity of P. niruri. Jurnal Teknologi (Sciences and Engineering), 68(5): 47-52.

14. Yunus, M. A. C., Zhari, S., Haron, S., Arsad, N. H., Idham, Z. and Ruslan, M. S. H. (2015). Extraction and identification of Vitamin E from Pithecellobium jiringan seeds using supercritical carbon dioxide. Jurnal Teknologi, 74(7): 29-33.

15. Yian, L., N., Setapar, S. H. M., Sharif, N. S. M., Ahmad, A., Khatoon, A., Yunus, M. A. C. and Muhamad I. I. (2013). Extraction of rubber (Hevea brasiliensis) seed oil using supercritical carbon dioxide and Soxhlet extraction. Research Journal of Chemistry and Environment, 17(10): 46-52.

16. Hartati, S. L. M., Yunus, M. A. C. and Aziz, A. A. (2014). Optimization of supercritical $\mathrm{CO}_{2}$ extraction of Swietenia mahagoni seed by response surface methodology. Jurnal Teknologi (Sciences and Engineering), 67(1): 15-20.

17. Aziz, A. H. A., Yunus, M. A. C., Arsad, N. H., Yian, L. N., Idham, Z. and Razak, A. Q. A. (2016). Optimization of supercritical carbon dioxide extraction of Piper betel Linn leaves oil and total phenolic content. IOP Conference Series: Materials Science and Engineering, 162(1): 1-7.

18. Yunus, M. A. C., Idham, Z. and Morad, N. A. (2015). Optimisation of squalene from palm oil mesocarp using supercritical carbon dioxide. $10^{\text {th }}$ Asian Control Conference (ASCC), 1-6. 
19. Danlami, J. M., Zaini, M. A. A., Arsad, A. and Yunus, M. A. C. (2015). A parametric investigation of castor oil (Ricinus comminis $\mathrm{L}$ ) extraction using supercritical carbon dioxide via response surface optimization. Journal of the Taiwan Institute of Chemical Engineers, 53: 32-39.

20. Akowuah, G. A., Ismail, Z., Norhayati, I. and Sadikun, A. (2005). The effects of different extraction solvents of varying polarities on polyphenols of Orthosiphon stamineus and evaluation of the free radical-scavenging activity. Food Chemistry, 93(2): 311-317.

21. Rithwan, F., Zhari, S., Yunus, M. A. C. and Hadzri, H. M. (2014). Efficacy of biological activity of Andrographis paniculata extracted by using supercritical carbon dioxide $\left(\mathrm{SC}-\mathrm{CO}_{2}\right)$ extraction. Jurnal Teknologi (Sciences and Engineering), 69(4): 61-64.

22. Sharif, K. M., Rahman, M. M., Azmir, J., Mohamed, A., Jahurul, M. H. A., Sahena, F. and Zaidul, I. S. M. (2014). Experimental design of supercritical fluid extraction - A review. Journal of Food Engineering, 124: 105-116.

23. Turkmen, N., Sari, F. and Velioglu, Y. S. (2006). Effects of extraction solvents on concentration and antioxidant activity of black and black mate tea polyphenols determined by ferrous tartrate and Folin-Ciocalteu methods. Food Chemistry, 99(4): 835-841. 